\section{Nonslip Breast Retractors with Cautery Tip Cleaners}

\author{
Jun Ho Lee, Sung-Eun Kim, Tae Gon Kim, \\ Yong-Ha Kim
}

Department of Plastic and Reconstructive Surgery, Yeungnam University College of Medicine, Daegu, Korea

\section{Correspondence: Jun Ho Lee}

Department of Plastic and Reconstructive Surgery, Yeungnam University College of Medicine, 170 Hyeonchung-ro, Nam-gu, Daegu 705-717, Korea Tel: +82-53-620-3482, Fax: +82-53-626-0705, E-mail: 2junho@gmail.com

Presented at the Oriental Society of Aesthetic Plastic Surgery 13th International Congress, October 5-7, 2012 in Seoul, Korea.

No potential conflict of interest relevant to this article was reported.

Received: 21 Feb 2013 • Revised: 13 Mar 2013 • Accepted: 18 Mar 2013 pISSN: 2234-6163 • elSSN: 2234-6171

http://dx.doi.org/10.5999/aps.2013.40.3.288 • Arch Plast Surg 2013;40:288-289

Copyright (c) 2013 The Korean Society of Plastic and Reconstructive Surgeons This is an Open Access article distributed under the terms of the Creative Commons Attribution Non-Commercial License (http://creativecommons.org/licenses/by-nc/3.0) which permits unrestricted non-commercial use, distribution, and reproduction in any medium, provided the original work is properly cited.

One of the challenges in breast surgery is to obtain the appropriate operative field because surgeons have to dissect deep spaces through minimal incision sites. In addition, muscle is a contractive structure, so retraction of slippery muscle tissue by stainless steel retractors can be a hindrance during surgery. To overcome this situation, breast retractors with toothed ends are made and sold (Fig. 1) [1, 2]. However, they are not produced in South Korea so they are not easy to obtain. They are also too expensive. The aim of this study is to introduce nonslip breast retractors constructed from conventional retractors and cautery tip cleaners.

Cautery tip cleaners (Xodus, New Kensinton, PA, USA) are composed of five layers (Fig. 2). Beginning with the top layer, the layers are nonslip paper, polyurethane foam, X-ray detectable material, acrylic adhesive tape, and release line. The top layer, nonslip paper, provides an abrasive surface. Using this surface, the cautery tip cleaners are intended to be used to remove and clean the material from the tips of monopolar and bi-polar cautery probes. Sometimes the cautery tip cleaners are used in surgical debridement to make a clean, flat, and even wound bed [3]. The procedure for constructing nonslip breast retractors using cautery tip cleaners is as follows:

1) Prepare normal retractors and cautery tip cleaners.

2) Trim the tip cleaners according to the size of the

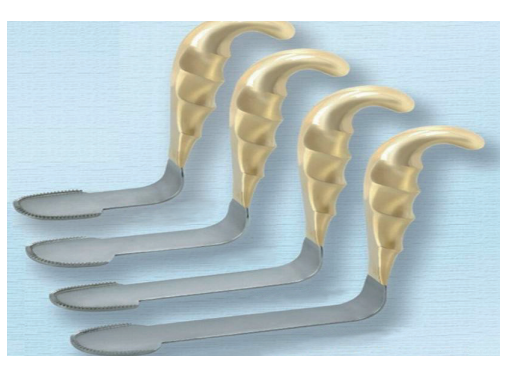

Fig. 1. Epstein breast retractor (ASSI, with permission from Accurate Surgical \& Scientific Instruments Co. [1]).

Fig. 3.

Various types of nonslip breast retractors with cautery tip cleaners.

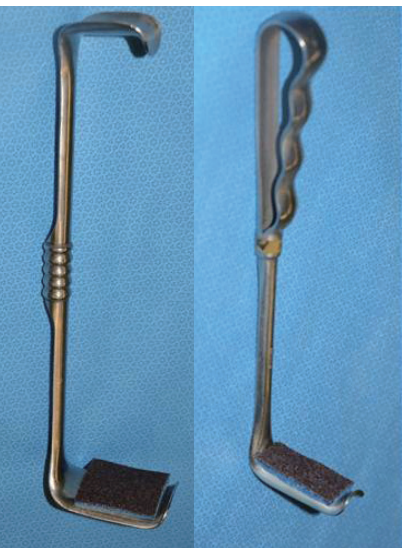

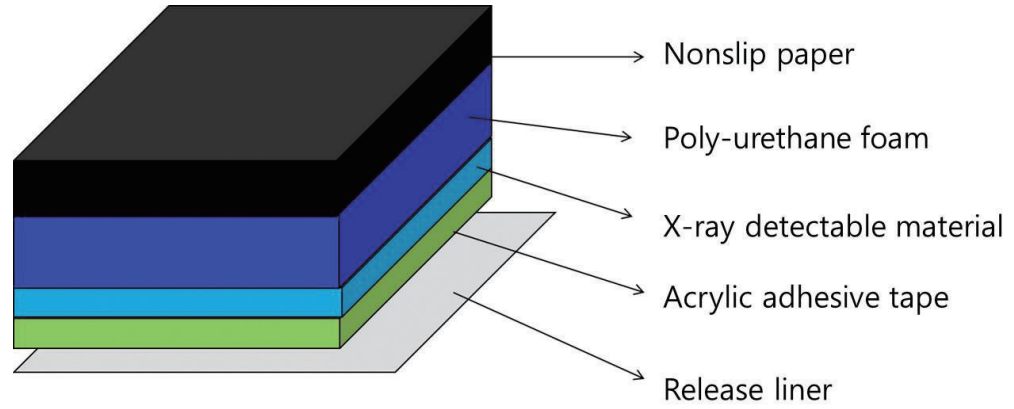

Fig. 2.

Composition of cautery tip cleaners (Xodus).

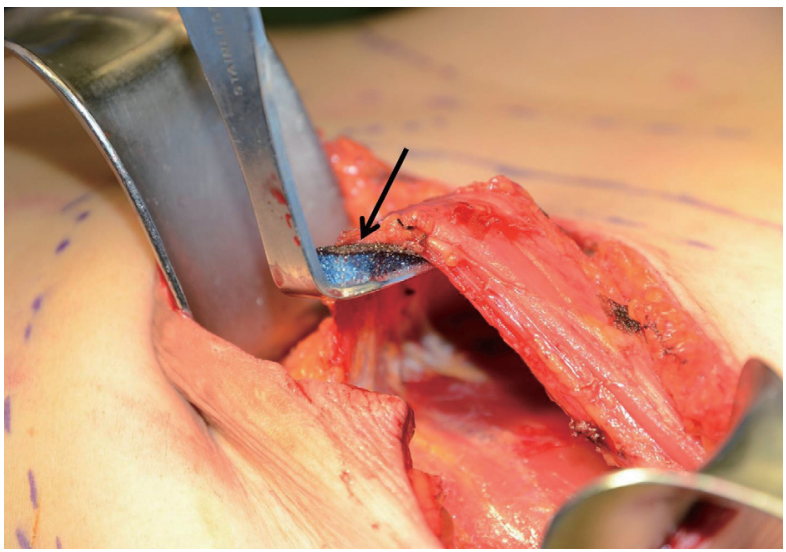

Fig. 4.

Retraction of slippery muscle by new breast retractors (black arrow) on immediate breast reconstruction. 
retractors.

3) Dry off the tip cleaners and the blade of the retractors completely for a firm bond between the two surfaces.

4) Remove the release line and put the tip cleaners on the retractors.

Tip cleaners could be applied to any retractors (Fig. 3). These retractors can be used for the dissection of the submuscular space. It is necessary to retract the muscle with care because the muscle fiber could be injured by the rough surface of the tip cleaner. When the retractors need to be adjusted, the blade of the retractors should not be slid while gripping, but should be removed from the muscle and moved to another point. If the number of the tip cleaners remaining on the retractors when closing the wound is not same as the initial number, a portable $\mathrm{X}$-ray should be used to locate and retrieve the lost tip cleaners.

During the period from February 2011 to February 2013, we applied this technique in 98 breast reconstruction cases (Fig. 4). In all of the cases, we achieved a better operative field, so that it was easier to dissect the muscle and control the bleeding in the submuscular area. We have never had any problems related to the tip cleaners, such as injury to the muscle during surgery. In any other breast surgery or submuscular dissection, the new retractors provided us with a better operative field and allowed the operation to be performed with greater ease.

New retractors can be constructed easily during surgery, so they are very cost-effective. They are attractive items to surgeons, providing a stable operative field and facilitating speedy, safe, and simple submuscular dissection.

\section{References}

1. Epstein MD. 2013 Accurate Surgical \& Scientific Instruments (ASSI) epstein breast retractors [Internet]. New York: ASSI; c2013 [cited 2013 Feb 20]. Available from http://www.epsteinplasticsurgery.com/pdf/ASSIEpstein-Breast-Retractor.pdf.

2. Accurate Surgical \& Scientific Instruments (ASSI).

Breast retractors without fiber optic or suction [Internet]. New York: ASSI; [cited 2013 Feb 20]. Available from http://www.accuratesurgical.com/docs/ breast_instrumentation/retractors/index.asp.

3. Choong MY, Wu HF, Lin CY, et al. Using electrosurgical tip cleaner to debride before skin grafting. Am Surg 2011;77:E296-7.

\section{Basal Cell Carcinoma Presenting as a Hypertrophic Scar}

Kwang-Ryeol Lim, Ka-Hyung Cho, So-Min Hwang, Yong-Hui Jung, Jennifer Kim Song

Aesthetic, Plastic and Reconstructive Surgery Center, Good Moonhwa Hospital, Busan, Korea

\begin{abstract}
Correspondence: Kwang-Ryeol Lim
Aesthetic, Plastic and Reconstructive Surgery Center, Good Moonhwa Hospital, 119 Beomil-ro, Dong-gu, Busan 601-803, Korea

Tel: +82-51-630-0199, Fax: +82-51-630-0145,E-mail: mdoc98@ hanmail.net

This study was presented at the 70th Congress of the Korean Society of Plastic and Reconstructive Surgeons on November 9-11, 2012, in Seoul, Korea.

No potential conflict of interest relevant to this article was reported.

Received: 1 Mar 2013 • Revised: 25 Mar 2013 • Accepted: 1 Apr 2013

pISSN: 2234-6163 • elSSN: 2234-6171

http://dx.doi.org/10.5999/aps.2013.40.3.289 • Arch Plast Surg 2013;40:289-291

Copyright (C) 2013 The Korean Society of Plastic and Reconstructive Surgeons

This is an Open Access article distributed under the terms of the Creative Commons

Attribution Non-Commercial License (http://creativecommons.org/licenses/by-nc/3.0/)

which permits unrestricted non-commercial use, distribution, and reproduction in any

medium, provided the original work is properly cited.
\end{abstract}

Basal cell carcinoma (BCC) is one of the most common skin malignancies. Its well-known etiologic factors include ultraviolet (UV) exposure, ionizing radiation, arsenal exposure, and genetic predisposition. Moreover, its etiological association with trauma or scar tissue has also been documented [1-3].

A 39-year-old woman visited us with the chief complaint of a hypertrophic scar occurring in the right supratip region (Fig. 1A). The patient had no past history of having abnormal symptoms or diseases in the right supratip region, but presented with a 10-month history of acne-like pustules. The patient also stated that the inflammation waxed and waned as the scars were frequently irritated during
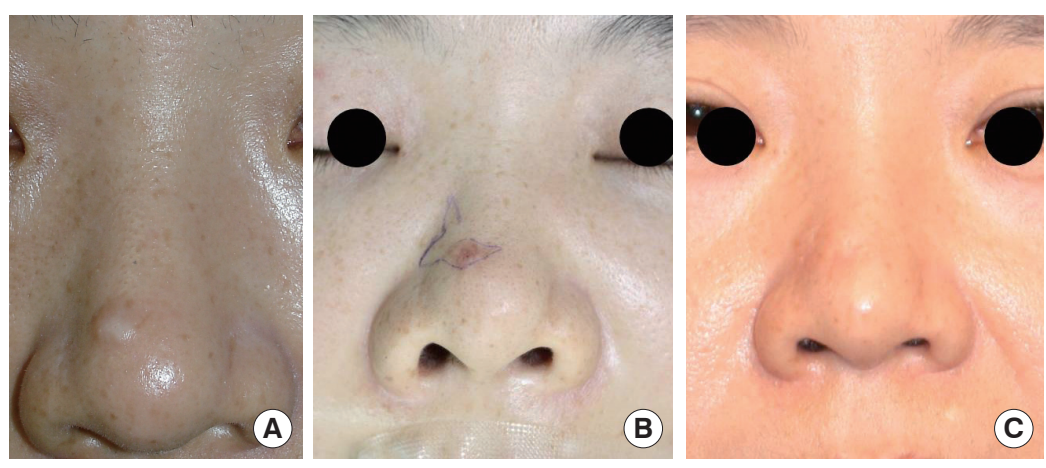

Fig. 1.

Clinical photos. (A) Preoperative view. A well-defined, $0.7 \mathrm{~cm} \times 0.7 \mathrm{~cm}$ round, skin-colored nodule on the nasal dorsum. (B) Intraoperative view. Surgical design using a bilobed flap. (C) Postoperative view. Good cosmetic results 12 months after excision. 